\title{
Expression of $100,000-M_{\mathrm{r}}$ Simian Virus 40 (SV40) Tumor Antigen in Mouse Fibroblasts Transfected with Replication-Defective SV40 Genomes
}

\author{
MICHAEL F. VERDERAME† AND ROBERT POLLACK* \\ Department of Biological Sciences, Columbia University, New York, New York 10027
}

Received 20 May 1985/Accepted 21 November 1985

\begin{abstract}
Simian virus $\mathbf{4 0}$ early region mutants which are partially or completely replication defective were tested for their ability to transform postcrissis mouse fibroblasts. All mutants tested were capable of generating anchorage-independent transformants. We have previously reported the presence of a variant tumor antigen of $100,000 M_{\mathrm{r}}(100 \mathrm{~K}$ protein) generated upon transformation by wild-type simian virus 40 virions which correlates with anchorage-independent growth (Chen et al., Mol. Cell. Biol. 1:994-1006, 1981). In this study, none of the mutants tested produced the $100 \mathrm{~K}$ variant protein at early (before the fifth) passage. Long-term passsage ( $>20$ weeks) permitted the expression of this $100 \mathrm{~K}$ variant in half of the transformants. Thus the phenotype of these mutants is different from both wild-type simian virus 40 (frequently production of $100 \mathrm{~K}$ by the third passage, and always by the tenth passage) and the origin-minus class of mutants (no production of $100 \mathrm{~K}$ at any passage).
\end{abstract}

Simian virus 40 (SV40) is a small DNA virus capable of generating tumors in rodents (16) and of transforming a variety of cells in culture $(1,3,4,24,30,35,40)$. In a nonpermissive interaction at least two early proteins, termed tumor antigens, are generated which correspond to the early proteins of the lytic growth cycle. The small tumor antigen, first reported by Prives and co-workers (33) $\left(M_{\mathrm{r}}, 17,000\right.$ [17Kprotein]), has an unknown function and seems to be dispensable for transformation in at least some species of cells (46). The large tumor antigen ( $\mathrm{T}$-ag), first described by Tegtmeyer et al. (44) (94K), is coded for by the same cistron but translated from a message produced by an alternate splicing of the primary RNA transcript (2). This protein has a multitude of functions including a weak poly(dT)stimulated ATPase activity $(15)$, specific $(22,36)$ and nonspecific $(8,38)$ DNA binding capability, and the ability to regulate its own synthesis $(37,44)$, to initiate viral DNA replication (43), to induce cellular DNA synthesis in the lytic cycle $(14,20,21)$, and to induce late transcription independent of viral replication $(7,23)$. The protein is bound to $(26)$ and stabilizes (28) a host embryonic protein (9) (54K in mouse cells and forms oligomers (6), and a small fraction of the protein is ADP ribosylated (19).

At present it is not clear which, if any, of these functions is necessary for the oncogenic potential of SV40. For instance, it has recently been demonstrated that the ability of $\mathrm{T}$-ag to bind specifically to the SV40 origin of replication and the ability to induce viral replication are not required for $\mathrm{T}$-ag to remain transformation competent $(17,42)$.

Under certain conditions, SV40-cell interactions can generate unusual proteins related to $\mathrm{T}-\mathrm{ag}$ of $100 \mathrm{~K}, 115 \mathrm{~K}$, or $130 \mathrm{~K}(10,25,47)$. Of these, the $100 \mathrm{~K}$ version is most commonly formed, although its presence seems to be restricted to mouse fibroblasts.

In a set of related mouse cell lines generated from a single line transformed by wild-type SV40 virus (SV101), the

\footnotetext{
* Corresponding author.

$\dagger$ Present address: Department of Microbiology and Immunology, University of California, San Francisco, CA 94143.
}

amount of $100 \mathrm{~K}$ protein correlated extremely well with the ability of the cells to grow in soft agarose when analyzed by rank correlation analysis (12). In these same related cell lines, the presence or absence of a specific set of defective early region DNA sequences was also shown to be related to the presence or absence of the protein that was larger than the wild-type protein (5).

Furthermore, a tandem repeat of the 5 ' portion of wildtype SV40 early region linked to a complete early region constructed in vitro is capable of expressing both $94 \mathrm{~K}$ and $100 \mathrm{~K} \mathrm{~T}$-ags in a transient monkey cell assay (27).

SV40 mutants which fail to replicate their viral DNA fall into at least two classes: (i) those with defective origins of replication, some of which are unable to bind T-ag (such as the ORI-negative mutants), and (ii) those with mutations in the $\mathrm{T}$-ag-coding region which render the $\mathrm{T}$-ag unable to initiate replication. Here, too, some mutant $\mathrm{T}$-ags (such as the T-ag from the SV40 mutant C2 [32]) can and some (for example the T-ag from the SV40 mutant C6 [39]) cannot bind to the SV40 origin of replication.

In past attempts to understand the genesis of the $100 \mathrm{~K}$ protein, an origin-defective (and therefore replicationdefective) mutant of SV40 was tested for its ability to generate $100 \mathrm{~K}$. Under no circumstances could this protein be detected in such ORI-negative transformed cells (11). This suggested that either viral DNA replication or T-ag binding to the viral origin of replication, or both, might be necessary events in the creation of $100 \mathrm{~K}$.

To complement our previous studies we have chosen to study the capacity of the C6 SV40 mutant to generate $100 \mathrm{~K}$ T-ag. The C6 DNA used in this study was recovered by recombinant DNA technology from a monkey cell line designated C6 which was isolated after infection of CV-I cells with SV40 virus which had been irradiated with UV light (18). Only replication-defective virus would be capable of transforming these cells, since replication-competent virus would have killed the cells. The SV40 early region recovered from these cells was shown to contain 3 base pair (bp) substitutions in the coding region of $\mathrm{T}$-ag. The parent mutant, as well as two different subclones containing respec- 
tively one or two of the three mutations, were tested for transforming ability in rat cells. All three mutants were found to have a transforming efficiency equal to wild-type SV40 in spite of the fact that the T-ag of C6 is incapable of initiating viral replication (17).

We have tested the C6 mutant and its subclones in mouse cells for the ability to generate the $100 \mathrm{~K}$ protein.

\section{MATERIALS AND METHODS}

Plasmids. Plasmids of the $\mathrm{C} 6$ lineage included $\mathrm{pK}$ (containing wild-type SV40), pC6 (the initial mutant isolated from SV40-transformed monkey cells containing 3 mutations at 5,074, 5,011, and 4,360 bp in the SV40 [46] numbering system), [pC6-1] (containing the mutations at 5,074 and 5,011 bp), and [pC6-2] (containing only the mutation at 4,360 bp). The mutation at $5,074 \mathrm{bp}$ changes a guanine to a thymine, resulting in a change of amino acid number 30 from a methionine to an isoleucine. The mutation at $5,011 \mathrm{bp}$ changes an adenine to a thymine and effects amino acid number 51 , changing it from a lysine to an asparagine. The change at 4,360 bp switches an adenine to a cytosine and amino acid number 153 from an asparagine to a threonine. The mutation in [pC6-2] maps to the region which has been identified as critical for the specific binding of wild-type T-ag to the SV40 origin of replication (31). Plasmids [pC6] and [pC6-2] are completely replication defective, and [pC6-1] replicates with about $1 / 100$ th the efficiency of wild-type SV40.

The plasmid [pK10] was constructed from a virus which grew out of a [pC6-1] infection of monkey cells. It is a second-site revertant with a third mutation at 4,977 bp (changing a guanine to an adenine and amino acid number 63 from a glutamine to a lysine). All pC6-related plasmids are described in detail elsewhere (17).

The plasmid containing the origin defective mutant of SV40 (pSVR1-ORI ${ }^{-}$) (11) was supplied by David Grass (Columbia University). It is referred to in this paper as pORI ${ }^{-}$.

All plasmids were prepared according to standard laboratory protocols.

Transformations. NIH $3 \mathrm{~T} 3$ cells (provided by $\mathrm{M}$. Wigler) were grown in Dulbecco modified Eagle medium (GIBCO Laboratories; 430-2100) supplemented with penicillin (100 $\mathrm{U} / \mathrm{ml})$, streptomycin $(100 \mu \mathrm{g} / \mathrm{ml})$, and $10 \%$ (vol/vol) fetal calf serum (GIBCO; lot no. 31P6223). Cells were prepared and transfected exactly as described previously (49). The day after the transfection, cells were split directly into $60-\mathrm{mm}$ dishes (Nunc) at $10^{5}$ cells per dish or into growth medium containing $0.33 \%$ agarose (Becton Dickinson and Co.) and $10 \%$ fetal calf serum, which was overlaid onto a base of $0.5 \%$ agarose in growth medium containing $10 \%$ fetal calf serum. Cells plated directly on plastic were switched to $1 \%$ fetal calf serum the second day after transfection, and all cells were subsequently fed twice weekly. Transformants were picked 2 to 3 weeks later as either dense foci in $1 \%$ serum or as colonies in agarose. Cells were recloned to pure populations (monitored by $\mathrm{T}$-ag nuclear fluorescent staining performed as described previously [48]) when necessary by plating $10^{2}$ cells onto a $60-\mathrm{mm}$ dish and picking a well-isolated colony approximately 2 weeks later. Cells were then routinely carried by plating $10^{3}$ cells per $60-\mathrm{mm}$ dish and transferring them to a new dish at the same density on the average 11.5 days later.

The part of the designation for each cell line which is in square brackets indicates the plasmid which was used to transform it, and the letter following it indicates which clone it was. For example, [pC6]-K was generated by the parental plasmid [pC6], and [pC6-1]-E1 was transformed by the plasmid [pC6-1]. A lowercase a indicates a selection through the agarose assay; otherwise clones were picked as dense foci in $1 \%$ fetal calf serum. Thus [pC6] a- $\mathrm{R}$ was a transformant originally picked from an agarose dish, and [pC6-1]-E2a1 is an agarose subclone of the [pC6-1]-E2 cell line.

Radiolabeling and immunoprecipitation of tumor antigens. Cells were plated at $5 \times 10^{5}$ cells onto a $60-\mathrm{mm}$ dish. The following day they were labeled with $100 \mu \mathrm{Ci}$ of $\left[{ }^{35}\right.$ S $]$ methionine (Amersham Corp.; $>700 \mu \mathrm{Ci} / \mathrm{mmol}$ ) per $\mathrm{ml}$ in Dulbecco modified Eagle medium minus methionine (GIBCO; lot no. 82-5040) plus $2 \%$ dialyzed fetal calf serum. After $4 \mathrm{~h}$ with intermittent rocking the dishes were rinsed thrice with phosphate-buffered saline $\left(4^{\circ} \mathrm{C}\right)$ and extracted with $1 \mathrm{ml}$ per dish of buffer containing $10 \mathrm{mM} \mathrm{N}-2$ hydroxyethylpiperazine- $N^{\prime}$-2-ethanesulfonic acid ( $\mathrm{pH} 8.0$ ), $0.14 \mathrm{M} \mathrm{NaCl}, 1 \mathrm{mM} \mathrm{MgCl}, 1 \%$ Nonidet P-40 (Bethesda Research Laboratories), and $300 \mu \mathrm{g}$ of freshly dissolved phenylmethylsulfonyl fluoride per $\mathrm{ml}$. After 20-min extractions the cells were scraped into a tube and spun at 2,000 $\times$ $g$ for $5 \mathrm{~min}$, and the supernatant was collected. Trichloroacetic acid-precipitable counts were determined at this point. The supernatant was then spun for at least $45 \mathrm{~min}$ at $48,000 \times g$ to remove particulate matter. Equal trichloroacetic acid-precipitable counts were brought to $1-\mathrm{ml}$ volumes with the extraction buffer, and one-half of each sample was incubated with $15 \mathrm{ml}$ of either normal hamster serum or serum from a hamster bearing an SV40 tumor. After at least $2 \mathrm{~h}$ on ice the immune complexes were collected for $20 \mathrm{~min}$ with $50 \mu \mathrm{l}$ of a $10 \%$ ( $\mathrm{vol} / \mathrm{vol}$ ) solution of IgSorb (The Enzyme Center) which had been previously washed in $1 \mathrm{M} \mathrm{NaCl}$ buffer (1 M NaCl, $5 \mathrm{mM}$ EDTA, $10 \mathrm{mM}$ Tris, $\mathrm{pH} \mathrm{8.0)}$ ). The precipitates were pelleted at $2,000 \times g$ for $5 \mathrm{~min}$ and washed once in $140 \mathrm{mM} \mathrm{NaCl}-5 \mathrm{mM}$ EDTA-10 mM Tris ( $\mathrm{pH} \mathrm{8.0)}$ and twice in the $1 \mathrm{M} \mathrm{NaCl}$ buffer. Proteins were eluted at $100^{\circ} \mathrm{C}$ as described previously (33). Proteins were separated on polyacrylamide gels prepared as described previously (33), but with an acrylamide/bisacrylamide ratio of 30:0.375. The gels were treated with $\mathrm{En}^{3} \mathrm{Hance}$ (New England Nuclear Corp.) and autofluorographed at $-70^{\circ} \mathrm{C}$ on Kodak SB-5 X-ray film.

Assays. Agarose assays were performed as described above for the transformation assay and scored 3 weeks later.

\section{RESULTS}

Early-passage pC6 transformants. Nineteen clonal cell lines from four different transfection experiments were subjected to analysis by immunoprecipitation and agarose assay. The cell lines included 12 lines from [pC6], 2 from [pC6-1], 3 from [pC6-2], 1 from [pK10], and one from the wild type [pK1].

Growth in agarose is well correlated with the ability to produce $100 \mathrm{~K}$ in wild-type systems (12). The absolute plating efficiency in agarose of each of these cell lines generated by the pC6 plasmids was therefore assayed (Table 1). All but two of the cell lines had a significant plating efficiency in agarose (i.e., greater than 100 -fold above background). Note, however, that all the transformed clones generated by C6 mutants are from 2- to 100-fold less efficient at growth in agarose than SV101, a standard full transformant (45) which is used in this laboratory as a reference. The difference in the ability of mutant-transformed cells to grow in soft agarose compared with wild type-transformed clones is even more pronounced when measured against [pK1]-L1, the wild-type transformant generated in this series of experiments. 
TABLE 1. Anchorage independence of pC-related mouse transformants

\begin{tabular}{llcc}
\hline \multicolumn{1}{c}{ Cell line } & Transformed by: & $\begin{array}{c}\text { Passage } \\
\text { no. }\end{array}$ & APE (\%) \\
\hline [pK1]-L1 & pK1 (wild type) & 12 & 9.1 \\
[pC6]-G1 & pC6 & 9 & 0.2 \\
[pC6]-J & pC6 & 9 & 2.2 \\
[pC6]-K & pC6 & 6 & 0.4 \\
[pC6]-L1 & pC6 & & ND $^{b}$ \\
[pC6]-L2 & pC6 & 8 & 0.75 \\
[pC6]-L3 & pC6 & 9 & 0.15 \\
[pC6]-L4 & pC6 & 11 & $<0.05$ \\
[pC6]a-R & pC6 & 4 & 3.1 \\
[pC6]-S & pC6 & 4 & 1.8 \\
[pC6]-T & pC6 & 4 & 0.05 \\
[pC6]a-U & pC6 & 4 & $1.0^{c}$ \\
[pC6]a-W & pC6 & 4 & 0.95 \\
[pC6-1]-E1 & pC6-1 & 15 & $0.07^{c}$ \\
[pC6-1]-E2 & pC6-1 & 14 & 0.30 \\
[pC6-2]-B & pC6-2 & 14 & $0.02^{c}$ \\
[pC6-2]-G1 & pC6-2 & 14 & $<0.05$ \\
[pC6-2]-K & pC6-2 & 10 & $0.13^{c}$ \\
[pK10] & pK10 & 11 & $0.10^{c}$ \\
SV101 & SV40 & & 4.9 \\
NIH3T3 & & & $<0.0005^{d}$ \\
\hline
\end{tabular}

${ }^{a}$ Plating efficiency in $0.33 \%$ agarose scored as visible colonies 3 weeks afte plating $10^{3}$ cells per dish (except where indicated). Average of two dishes.

${ }^{b} \mathrm{ND}$, Not determined.

c $10^{4}$ cells per dish.

${ }^{d} 10^{5}$ cells per dish.

Fig. 1 shows a representative immunoprecipitation of several of these cell lines at early passage (earlier than passage 10). The particular clone generated by $\mathrm{pK} 1$ produces more $100 \mathrm{~K}$ than $94 \mathrm{~K}$ and was used to clearly indicate the position of $100 \mathrm{~K}$ (Fig. 1, lane g). Note that none of the cell lines in this particular panel, other than SV101 and [pK1]-Ll, demonstrates detectable $100 \mathrm{~K} \mathrm{~T}$-ag, whereas all have similar amounts of $94 \mathrm{~K}$ T-ag.

The positive control SV101 (Fig. 1) has only small amounts of detectable $100 \mathrm{~K}$ relative to $94 \mathrm{~K}$, especially when compared with [pK1]-L. An exposure sixfold lower than the one used to make Fig. 1 was the minimum exposure necessary to reveal $100 \mathrm{~K}$ in a low-level producer such as SV101. Since a sixfold increase in the minimum exposure necessary to detect $100 \mathrm{~K}$ did not reveal any additional cell lines producing detectable $100 \mathrm{~K}$, we can confidently say that there is no detectable $100 \mathrm{~K}$ in any of the cell lines represented by this autoradiogram. Four other autoradiograms chosen at random (representing 26 different samples) were overexposed an average of four times the minimum exposure necessary to detect $100 \mathrm{~K}$ in the positive control lane. None of the cell lines examined in this analysis had detectable $100 \mathrm{~K}$, even after the longer exposures. All autoradiograms contained a positive control and were carefully examined for the presence or absence of $100 \mathrm{~K}$. On the basis of these experiments we feel confident that we have not overlooked any cell line expressing detectable $100 \mathrm{~K}$.

The results of all the immunoprecipitations on primary transformants generated with the C6 set of mutants are summarized in Table 2 . There are three facts to note based on these results. First, the wild type-transformed clone had detectable $100 \mathrm{~K}$ protein as soon as it was examined (passage 3 ). This is consistent with previous results (11). In contrast, the clones generated by C6 mutant DNAs usually did not express detectable $100 \mathrm{~K} \mathrm{~T}$-ag until several passages later, and some still have not expressed detectable $100 \mathrm{~K}$ after several months in culture. At least one member of each class has generated $100 \mathrm{~K}$, indicating all the mutants examined here retain that capacity, although the time of appearance varies when compared with wild-type situations. Second, none of the transformants generated by these mutants expresses amounts of $100 \mathrm{~K}$ equal to the amount of $94 \mathrm{~K}$ present. This is in contrast to the particular wild-type transformant generated in this study and also in contrast to other $100 \mathrm{~K}$-containing cells. Third, none of the cell lines generated with the mutant DNAs grows as well in soft agarose as wild-type transformants. This is consistent with previous results which demonstrated a correlation between growth in agarose and expression of $100 \mathrm{~K}(12)$.

Agarose subclones of pC6-related transformants. Passage through agarose of cells transformed by wild-type virus can select for cells which now produce $100 \mathrm{~K}(12)$. Subclones were picked from agarose of each of the following cell lines: two from [pK1]-L, four from [pc6]-J, two from [pC6]-L4, four from [pC6-1]-E2, four from [pC6-2]-G1, four from [pC62]-K, and four from [pK10]-H. Figure 2 shows a typical immunoprecipitation of these subclones. The data for all of the subclones examined are summarized in Table 3 . In spite of the selection through agarose, by passage 6 none of the subclones from the parental mutant [pC6] produced detectable $100 \mathrm{~K}$. Two of the four subclones of [pC6-1]-E2 now produced $100 \mathrm{~K}$. None of the total of eight subclones from [pC6-2] transformed cells produced detectable $100 \mathrm{~K}$, and none of the four subclones from [pK10]-H produced the larger protein. Although subclones derived from transformants produced by mutant DNAs were not passaged as long as the ones indicated in Table 2, their failure to make $100 \mathrm{~K}$ after agarose subcloning distinguishes them clearly from wildtype agarose subclones (11).

\section{DISCUSSION}

Many mouse cell lines transformed by SV40 contain a variant $\mathrm{T}$-ag which migrates similarly to the protein we call $100 \mathrm{~K}(13,25,33,41)$. Tryptic peptide maps have shown that

TABLE 2. $100 \mathrm{~K} \mathrm{~T}$-ag versus passage in pC6-related mouse transformants ${ }^{a}$

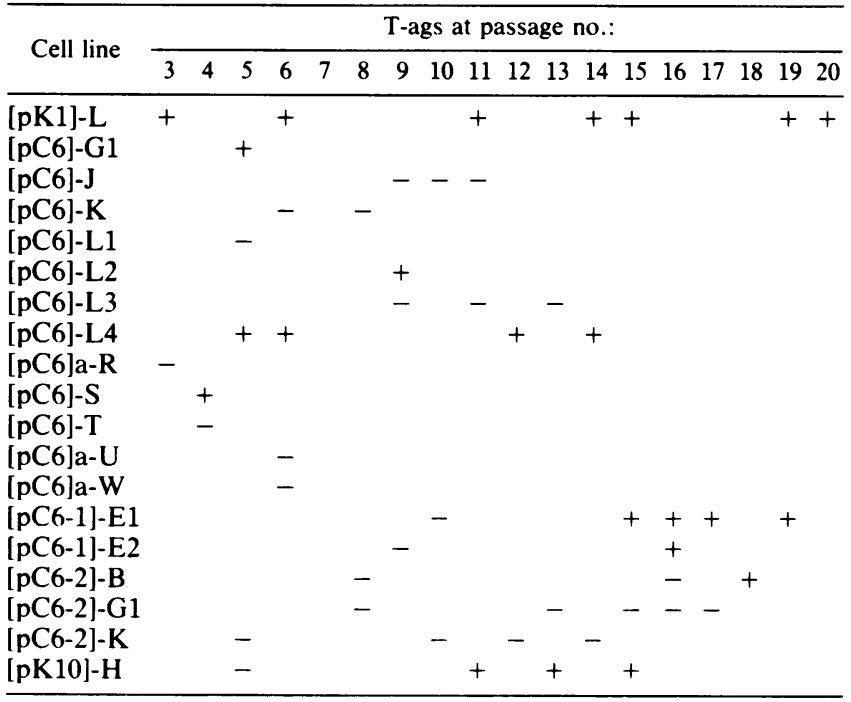

${ }^{a}-$, Presence of only wild-type $94 \mathrm{~K}$ when assayed at the indicated passage: + , presence of both $94 \mathrm{~K}$ and $100 \mathrm{~K}$. All determinations of presence or absence of $100 \mathrm{~K}$ were made in ignorance of the cell line or passage number. 


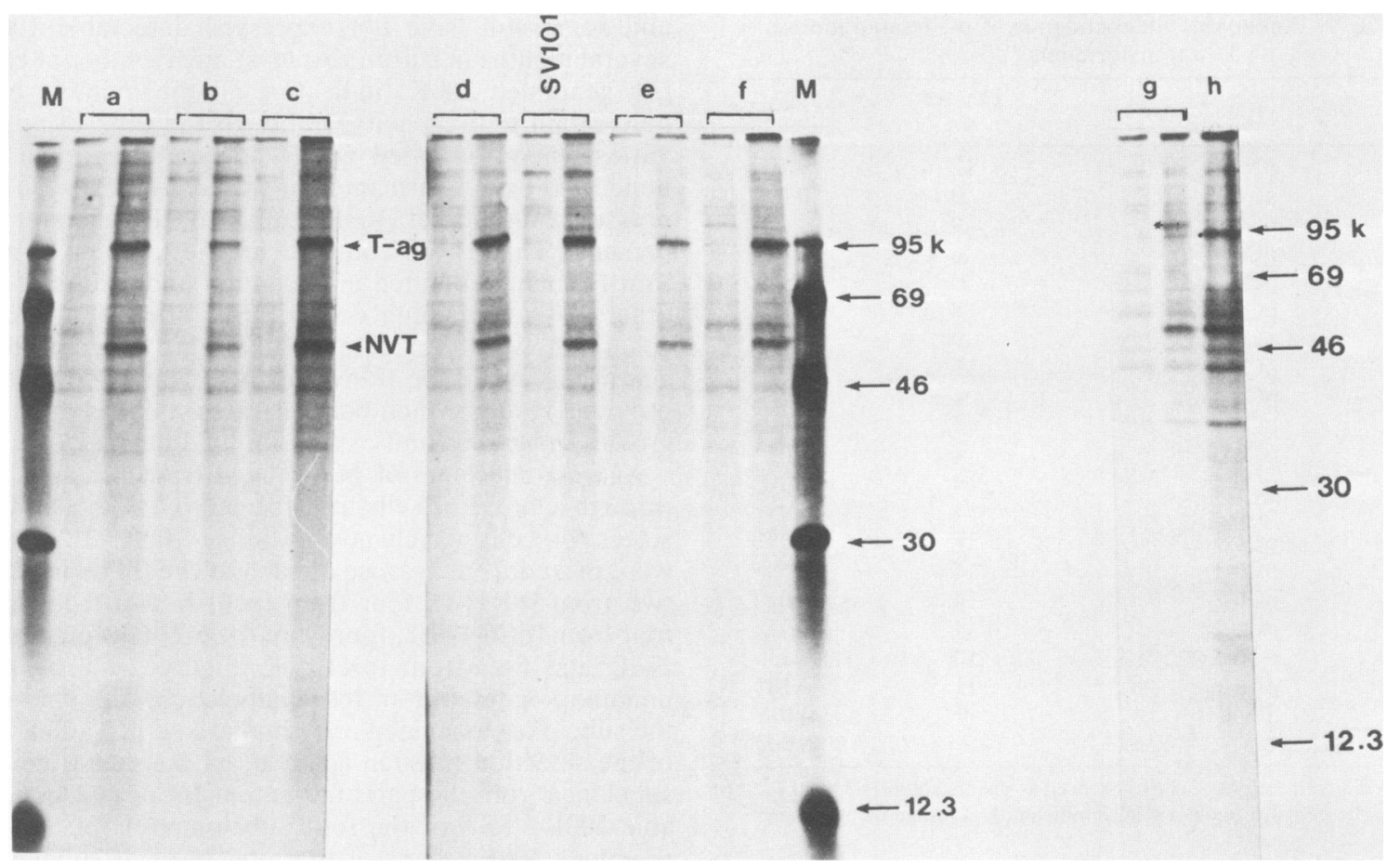

FIG. 1. Autofluorogram of an immunoprecipitation of pC6-related mouse transformants separated on $15 \%$ acrylamide gels. Lanes (passage numbers): a, [pC6-2]-K (5); b, [pC6]-L1 (5); c, [pC6-2]-G1 (9); d, [pC6-1]-E1 (10); e, [pK10]-H (5); f, [pC6-1]-E2 (9); g, [pK1]-L (6); h, [pC6]-Ll (5); M, molecular weight markers. The left lane of each pair contained control serum, and the right lane contained hamster antitumor serum. Note the presence of both wild-type $94 \mathrm{~K}$ and 100K T-ags (indicated by the star) in [pK1]-L (lane g). None of the pC6-related transformants expressed $100 \mathrm{~K}$ at early passage. SV101 is a cell line transformed by wild-type SV40 which contains both proteins. The faint band in lane c is not $100 \mathrm{~K}$. On the original autoradiogram it clearly migrates slower than the $100 \mathrm{~K}$ band, and comigrates with a background band seen in other lanes (including normal serum lanes) on longer exposures. Also, the marker lane on the left side is slightly lower due to edge effects during the running of the gel.

there are only minor differences between the $100 \mathrm{~K}$ protein we detect and that which is detected by other workers (S. Chen, personal communication). Others have shown that there is no detectable difference between the $\mathrm{N}$ termini (41), C termini (13), or tryptic peptide ion-exchange chromatography elution profiles (25) of authentic T-ag and this $100 \mathrm{~K}$ protein. However, since a similar T-ag that is larger than the wild-type $\mathrm{T}$-ag can be detected in a cell-free system primed with mRNA from the SV40-transformed mouse cell line SV3T3 (34), and since $100 \mathrm{~K}$ production requires the presence of a partial tandem repeat of the SV40 early region (27), it is very likely that $94 \mathrm{~K}$ and $100 \mathrm{~K}$ differ in their primary amino acid sequence.

Previous work had suggested that SV40 DNA replication might be a prerequisite to the production of this protein. Of 10 transformants produced by wild-type SV40 plasmids, 7 contained $100 \mathrm{~K}$ initially (passage 3 ) and all expressed the variant protein as well as $94 \mathrm{~K}$ after several weeks in culture (11). In contrast, viral mutants lacking an origin of replication (and therefore completely replication defective) make no detectable $100 \mathrm{~K}$ at any passage (11).

With these facts in mind we tested the ability of the C6-related plasmids, which synthesize T-ags that are completely (pC6, pC6-2) or partly (pC6-1) defective for the initiation of SV40 DNA synthesis, for their ability to generate transformed cell lines which have a $100 \mathrm{~K}$ T-ag. Only 4 of 18 clones transformed by replication-defective $\mathrm{T}$-ags had $100 \mathrm{~K}$ at first examination. After several weeks in culture (some cell lines for as long as 6 months) 9 of 18 clones still did not express $100 \mathrm{~K}$. Thus we conclude that C6 mutants are partially defective in their ability to generate $100 \mathrm{~K} \mathrm{~T}$-ag.

When agarose subclones of transformed cell lines generated with wild-type SV40 plasmids are examined, 8 out of 8 of them contain $100 \mathrm{~K} \mathrm{~T}-\mathrm{ag}$, including those from clones that were not expressing $100 \mathrm{~K}$ before passage in agarose (11). This is in contrast to the results seen here with the C6 mutants. Only 2 of 24 subclones of various C6-derived transformants expressed detectable $100 \mathrm{~K}$ protein immediately after agarose subcloning.

Previous work from this laboratory indicated a correlation between the ability to grow in soft agarose and the presence of $100 \mathrm{~K}$ when the original transformants were generated by SV40 virions (12). The results presented here are consistent with that observation to a limited extent. None of the transformants generated by the C6 mutants exhibited $100 \mathrm{~K}$ in amounts comparable to SV101 or to [pK1]-L1. This may indicate low but undetectable levels of $100 \mathrm{~K}$ correlating with the lower ability of these cells to grow in agarose when compared with wild type-generated clones. However some mutant-derived transformants (e.g., [pC6]-J) did not express detectable $100 \mathrm{~K}$ yet grew fairly well in agarose $(2.2 \%$ plating efficiency). This may indicate that when $100 \mathrm{~K}$ generation is difficult or impossible other pathways are followed which result in anchorage-independent growth. This phenomenon has already been observed in origin-negative transformants (11). Also, spontaneous (non-SV40-dependent) anchorageindependent cells clearly arise in the absence of any SV40 T-ags. 


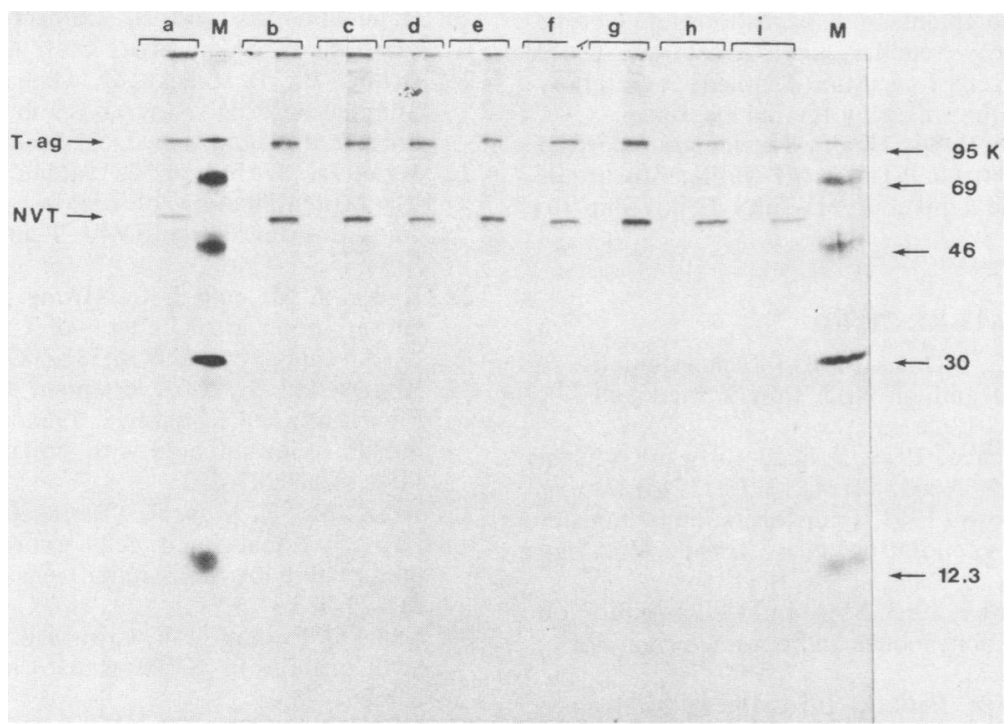

FIG. 2 Autofluorogram of immunoprecipitations of subclones derived from pC6-related transformants. Lanes: a, [pC6]-L4-a2; b, [pC6-1]-E1-a3; c, [pC6-1]-E1-a4; d, [pC6-1]-E2-a4; e, [pC6-2]-G1-a3; f, [pC6-2]-G1-a4; g, [pC6-2]-K-a2; h, [pC6-2]-K-a3; i, [pK10]-H-a2; M, molecular weight markers. All cells were assayed at passage 4 after subcloning. A summary of the results of all the immunoprecipitations done with subclones appears in Table 3 . On the original autoradiogram lane $\mathrm{c}$ had a weak $100 \mathrm{~K}$ band. Otherwise, all clones assayed in this experiment had no detectable $100 \mathrm{~K}$.

The genesis of $100 \mathrm{~K}$ is still an open question. Given the apparent ubiquitous presence of this variant T-ag in mouse cell transformants generated in several laboratories with several strains and stocks of wild-type SV40, it seems reasonable to assume that, during the acute phase of SV40

TABLE 3. $100 \mathrm{~K} \mathrm{~T}$-ag versus passage in subclones of pC6-related mouse transformants ${ }^{a}$

\begin{tabular}{|c|c|c|c|c|c|c|}
\hline \multirow{2}{*}{ Cell line } & \multicolumn{6}{|c|}{ T-ags at passage no.: } \\
\hline & 1 & 2 & 3 & 4 & 5 & 6 \\
\hline [pK1]-L-a1 & & & & & + & + \\
\hline $\begin{array}{l}\text { [pK1]-L-a2 } \\
{[\mathrm{pC} 6]-\mathrm{J}-\mathrm{a} 1}\end{array}$ & & & & + & & \\
\hline $\begin{array}{l}\text { [pC6]-J-a1 } \\
{[\mathrm{pC} 6]-\mathrm{J}-\mathrm{a} 2}\end{array}$ & & & & - & & - \\
\hline $\begin{array}{l}\text { [pC6]-J-a2 } \\
{[\mathrm{pC} 6]-\mathrm{J}-\mathrm{a} 3}\end{array}$ & & & & - & - & - \\
\hline $\begin{array}{l}{[\mathrm{pC} 6]-J-\mathrm{a} 3} \\
{[\mathrm{pC6}]-\mathrm{J}-\mathrm{a} 4}\end{array}$ & & & & & & - \\
\hline $\begin{array}{l}\text { [pC6]-J-a4 } \\
\text { [pC6]-L4-a1 }\end{array}$ & & & & & - & - \\
\hline $\begin{array}{l}\text { [pC6]-L4-a1 } \\
\text { [pC6]-L4-a2 }\end{array}$ & & & & & & - \\
\hline $\begin{array}{l}\text { [pC6]-L4-a2 } \\
\text { [pC6-1]-E1-a3 }\end{array}$ & & & & - & - & \\
\hline [pC6-1]-E1-a3 & & & & - & & \\
\hline [pC6-1]-E1-a4 & & & & + & & \\
\hline [pC6-1]-E2-a1 & & & & & + & \\
\hline [pC6-1]-E2-a2 & & & & & - & \\
\hline [pC6-1]-E2-a3 & & & & - & + & \\
\hline [pC6-1]-E2-a4 & & & & - & & \\
\hline [pC6-2]-G1-a1 & & & & - & & - \\
\hline [pC6-2]-G1-a2 & & & & & & - \\
\hline [pC6-2]-G1-a3 & & & & - & - & \\
\hline [pC6-2]-G1-a4 & & & & - & - & \\
\hline [pC6-2]-K-al & & & & & - & - \\
\hline [рC6-2]-K-a2 & & & & & - & \\
\hline [pC6-2]-K-a3 & & & & - & - & \\
\hline [pC6-2]-K-a4 & & & & - & & \\
\hline [pK10]-H-al & & & & - & - & - \\
\hline [pK10]-H-a2 & & & & & - & \\
\hline [pK10]-H-a3 & & & & - & & \\
\hline [pK10]-H-a4 & & & & - & & \\
\hline
\end{tabular}

\footnotetext{
"See footnote $a$ of Table 2
}

infection of mouse cells some specific mechanism is at work which consistently generates this $\mathrm{T}$-ag-related polypeptide.

In two cases the DNA sequences which encode the information for the production of $100 \mathrm{~K} \mathrm{~T}$-ag have been cloned. Analysis of the sequence indicates that a partial repeat of the SV40 early region is sufficient to generate $100 \mathrm{~K}$ (27). One speculation is that this particular type of duplication arises during the few rounds of viral DNA replication which follow infection or transfection of mouse cells. This would be consistent with the hypothesis that replication is required for the generation of $100 \mathrm{~K} \mathrm{~T}$-ag.

Although we do not completely understand the generation of this $100 \mathrm{~K}$ protein in cells transformed by the mutants which are completely replication defective (pC6 and pC6-2), it should be pointed out that the viral origin of replication is still intact and presumably still capable of being activated by cellular factors in lieu of functional $\mathrm{T}$-ag. $\mathrm{T}$-ag can induce cellular replication $(14,20,21)$. Perhaps the host molecules which normally act on cellular origins of replication can induce SV40 replication from the viral origin of replication in a complementary fashion, albeit very inefficiently.

We conclude from these studies that unlike wild-type SV40, which generates sequences encoding $100 \mathrm{~K}$ at high frequency in transformation and after passage through agarose, C6-type mutants can only produce $100 \mathrm{~K}$ after extended time in culture and then only occasionally, perhaps only through unknown host factors acting on the integrated DNA.

While this manuscript was in preparation, Manos and Gluzman (29) reported that the replicative function of SV40 $\mathrm{T}$-ag is important in generating $100 \mathrm{~K} \mathrm{~T}$-ag. They based this conclusion on the inability of other SV40 mutants in the C series to produce $100 \mathrm{~K}$ when used to transform mouse cells.

\section{ACKNOWLEDGMENTS}

We thank Yakov Gluzman for providing the C6 mutant plasmids and for helpful discussions and David Grass for providing the pORI ${ }^{-}$. We also thank Suzie Chen for allowing us to cite her unpublished 
results and for many helpful comments and suggestions and George Blanck, Alexandra Levitt, Arno Scheller, Lori Covey, and Carol Prives for extremely helpful discussions. Mark Kennedy is gratefully acknowledged for expert help in preparing the manuscript.

This work was supported by Public Health Service grants 5 ROI CA 25066 and 1 POI CA 33620 (to R.P.) from the National Institutes of Health and by a Columbia University Faculty Fellowship (to M.F.V.)

\section{LITERATURE CITED}

1. Ashkenazi, A., and J. L. Melnick. 1963. Tumorigenicity of simian papovavirus SV40 and of virus transformed cells. J. Natl. Cancer Inst. 30:1227-1268.

2. Berk, A. J., and P. A. Sharp. 1978. Spliced early mRNAs of simian virus 40. Proc. Natl. Acad. Sci. USA 75:1274-1278.

3. Black, P. H., and W. P. Rowe. 1963. Transformation in hamster kidney monolayers by vacuolating virus SV40. Virology 19:107-109.

4. Black, P. H., and W. P. Rowe. 1963. SV40-induced proliferation of tissue culture cells of rabbit, mouse and porcine origin. Proc. Soc. Exp. Biol. Med. 114:721-727.

5. Blanck, G., S. Chen, and R. Pollack. 1983. Intergration, loss, and reacquisition of viral DNA in SV40 transformed mouse cells. Virology 26:413-428.

6. Bradley, M. K., J. D. Griffen, and D. M. Livingston. 1982. Relationship of oligomerization to enzymatic and DNA binding properties of the SV40 large T-antigen. Cell 28:125-134.

7. Brady, J., J. B. Bolen, M. Radonovich, N. Salzman, and G. Khoury. 1984. Stimulation of simian virus 40 late gene expression by simian virus 40 tumor antigen. Proc. Natl. Acad. Sci. USA 81:2040-2044.

8. Carroll, R. B., L. Hager, and R. Dulbecco. 1974. Simian virus 40 $T$ antigen binds to DNA. Proc. Natl. Acad. Sci. USA 71:3754-3757.

9. Chandrasekaran, K., V. W. McFarland, D. T. Simmons, M. Dziadek. E. G. Gurney, and P. T. Mora. 1981. Quantitation and characterization of a species-specific and embryo stagedependent 55-kilodalton phosphoprotein also present in cells transformed by simian virus 40 . Proc. Natl. Acad. Sci. USA 78:6953-6957.

10. Chang, C., D. T. Simmons, M. A. Martin, and P. T. Mora. 1979. Identification and partial characterization of new antigens from simian virus 40-transformed mouse cells. J. Virol. 31:463-471.

11. Chen, S., D. S. Grass, G. Blanck, N. Hoganson, J. L. Manley, and R. E. Pollack. 1983. A functional SV40 origin of replication is required for the generation of $100 \mathrm{~K}$ super $\mathrm{T}$-antigen in transformed mouse cells. J. Virol. 48:492-502.

12. Chen, S., M. Verderame, A. Lo, and R. Pollack. 1981. Non-lytic SV40-specific $100 \mathrm{~K}$ phosphoprotein is associated with anchorage-independent growth in simian virus 40-transformed and revertant mouse cell lines. Mol. Cell. Biol. 1:994-1006.

13. Denhardt, D. T., and L. V. Crawford. 1980. Simian virus 40 T-antigen: identification of tryptic peptides in the C-terminal region and definition of the reading frame. J. Virol. 34:315-329.

14. Gershon, D., L. Sachs, and E. Winocour. 1966. The induction of cellular DNA synthesis by SV40 in contact-inhibited and in $\mathrm{X}$-irradiated cells. Proc. Natl. Acad. Sci. USA 56:918-925.

15. Giacherio, D., and L. Hager. 1979. A poly-(dT) stimulated ATPase activity associated with SV40 large T-antigen. J. Biol. Chem. 254:8113-8116.

16. Girardi, A. J., B. H. Sweet, V. B. Slotnick, and M. R. Hilleman. 1962. Development of tumors in hamsters inoculated in the neonatal period with vacuolating virus, SV40. Proc. Soc. Exp. Biol. Med. 109:649-660.

17. Gluzman, Y., and B. Ahrens. 1982. SV40 early mutants that are defective for viral DNA synthesis but competent for transformation of cultured rat and simian cells. Virology 123:78-92.

18. Gluzman, Y., J. Davidson, M. Oren, and E. Winocour. 1977. Properties of permissive monkey cells transformed by UVirradiated simian virus 40. J. Virol. 22:256-266.

19. Goldman, N., M. Brown, and G. Khoury. 1981. Modification of SV40 T-antigen by poly ADP-ribosylation. Cell 24:567-572.
20. Hatanaka, M., and R. Dulbecco. 1966. Induction of DNA synthesis by SV40. Proc. Natl. Acad. Sci. USA 56:736-740.

21. Henry, P., P. Black, M. Oxman, and S. Weissman. 1966. Stimulation of DNA synthesis in mouse cell line 3T3 by SV40. Proc. Natl. Acad. Sci. USA 56:1170-1176.

22. Jessel, D., J. Hudson, T. Landau, D. Tenen, and D. Livingston. 1976. Identification of regions of the SV40 genome which contain preferential SV40 T-antigen binding sites. Cell 8: 535-545.

23. Keller, J. M., and J. C. Alwine. 1984. Activation of the SV40 late promoter: direct effects of $\mathrm{T}$ antigen in the absence of viral DNA replication. Cell 36:381-389.

24. Koprowski, H., J. A. Pointen, F. Jensen, R. G. Ravdin, P. Moorhead, and E. Saksela. 1962. Transformation of cultures of human tissue infected with simian virus SV40. J. Cell. Comp. Physiol. 59:281-292.

25. Kress, M., E. May, R. Cassingena, and P. May. 1979. Simian virus 40-transformed cells express new species of proteins precipitable by anti-simian virus 40 tumor serum. J. Virol. 31:472-483.

26. Lane, D. P., and L. V. Crawford. 1979. T antigen is bound to a host protein in SV40 transformed cells. Nature (London) 278:261-263.

27. Levitt, A., S. Chen, G. Blanck, D. George, and R. Pollack. 1985. Two integrated partial repeats of SV40 together code for a super T-antigen. Mol. Cell. Biol. 5:742-750.

28. Linzer, D. I. H., W. Maltzman, and A. J. Levine. 1979. The SV40 A gene product is required for the production of a 54,000 cellular tumor antigen. Virology 98:308-318.

29. Manos, M. M., and Y. Gluzman. 1985. Genetic and biochemical analysis of transformation- competent replication-defective simian virus 40 large T-antigen mutants. J. Virol. 53:120-127.

30. Ponten, J. A., F. Jensen, and H. Koprowski. 1963. Morphological and virological investigation of human tissue cultures transformed with SV40. J Cell. Comp. Physiol. 61:145-154.

31. Prives, C., B. Barnet, A. Scheller, G. Khoury, and G. Jay. 1982. Discrete regions of the simian virus 40 large $T$ antigen are required for nonspecific and viral origin-specific DNA binding. J. Virol. 43:73-82.

32. Prives, C., L. Covey, A. Scheller, and Y. Gluzman. 1983. DNA binding properties of simian virus $40 \mathrm{~T}$ antigen mutants defective in viral replication. Mol. Cell. Biol. 3:1958-1966.

33. Prives, C., E. Gilboa, M. Revel, and E. Winocour. 1977. Cell free translation of SV40 early mRNA coding for viral T-antigen. Proc. Natl. Acad. Sci. USA 74:457-461.

34. Prives, C., Y. Gluzman, and E. Winocour. 1978. Cellular and cell-free synthesis of simian virus $40 \mathrm{~T}$-antigen in permissive and transformed cells. J. Virol. 25:587-595.

35. Rabson, A. S., and R. L. Kirschstein. 1962. Induction of malignancy in vitro in newborn hamster kidney tissue infected with simian vacuolating virus (SV40). Proc. Soc. Exp. Biol. Med. 111:323-328.

36. Reed, S. I., T. Fergusin, R. W. Davis, and G. Stark. 1975. T-antigen binds to SV40 DNA at the origin of replication. Proc. Natl. Acad. Sci. USA 72:1605-1609.

37. Reed, S. T., G. R. Stark, and J. C. Alwine. 1976. Autoregulation of simian virus 40 A gene by T antigen. Proc. Natl. Acad. Sci. USA 73:3083-3087.

38. Rundell, K., J. Collins, P. Tetgmeyer, H. Ozer, C.-J. Lai, and D. Nathans. 1977. Identification of simian virus 40 A protein. J. Virol. 21:636-646.

39. Scheller, A., L. Covey, B. Barnet, and C. Prives. 1982. A small subclass of SV40 T-antigen binds to the viral origin of replication. Cell 29:375-383.

40. Shein, H. M., and J. F. Enders. 1962. Transformation induced by simian virus 40 in human renal cell cultures. I. Morphology and growth characteristics. Proc. Natl. Acad. Sci. USA 48: 1164-1172.

41. Smith, A. E., R. Smith, and E. Paucha. 1982. Characterization of different tumor antigens present in cells transformed by simian virus 40. Cell 19:336-346.

42. Stringer, J. R. 1982. Mutant of SV40 large T-antigen that is defective for viral DNA synthesis, but competent for transfor- 
mation of cultured rat cells. J. Virol. 42:854-864.

43. Tegtmeyer, P. 1972. SV40 DNA synthesis: the viral replicon. J. Virol. 10:591-598.

44. Tegtmeyer, P., M. Schwartz, J. K. Collins, and K. Rundell. 1975. Regulation of tumor antigen synthesis by simian virus $40 \mathrm{~A}$ gene. J. Virol. 16:168-178.

45. Todaro, G., and H. Green. 1966. High frequency of SV40 transformation of mouse cell line 3T3. Virology 28:756-762.

46. Tooze, J. 1980. DNA tumor viruses. Cold Spring Harbor Laboratory, Cold Spring Harbor, N.Y.
47. Van Roy, F., L. Fransen, and W. Fiers. 1981. Phosphorylation patterns of tumor antigens in cells lytically infected or transformed by simian virus 40. J. Virol. 40:28-44.

48. Verderame, M., D. Alcorta, M. Egnor, K. Smith, and R. Pollack. 1980. Cytoskeletal F-actin patterns quantitated with fluoresceinisothiocynate phalloidin in normal and transformed cells. Proc. Natl. Acad. Sci. USA 77:6624-6628.

49. Wigler, M., A. Pellicer, S. Silverstein, and R. Axel. 1978. Biochemical transfer of single-copy eukaryotic genes using total cellular DNA as donor. Cell 14:725-731. 